University of Nebraska - Lincoln

DigitalCommons@University of Nebraska - Lincoln

Faculty Publications from the Harold W. Manter Laboratory of Parasitology

6-1967

\title{
A Consideration of Infraspecific Categories in the Genus Echinococcus Rudolphi, 1801 (Cestoda: Taeniidae)
}

Robert L. Rausch

University of Washington, rausch@uw.edu

Follow this and additional works at: https://digitalcommons.unl.edu/parasitologyfacpubs

Part of the Parasitology Commons

Rausch, Robert L., "A Consideration of Infraspecific Categories in the Genus Echinococcus Rudolphi, 1801 (Cestoda: Taeniidae)" (1967). Faculty Publications from the Harold W. Manter Laboratory of Parasitology. 346.

https://digitalcommons.unl.edu/parasitologyfacpubs/346

This Article is brought to you for free and open access by the Parasitology, Harold W. Manter Laboratory of at DigitalCommons@University of Nebraska - Lincoln. It has been accepted for inclusion in Faculty Publications from the Harold W. Manter Laboratory of Parasitology by an authorized administrator of DigitalCommons@University of Nebraska - Lincoln. 


\title{
A CONSIDERATION OF INFRASPECIFIC CATEGORIES IN THE GENUS ECHINOCOCCUS RUDOLPHI, 1801 (CESTODA: TAENIIDAE)
}

\author{
Robert L. Rausch \\ Arctic Health Research Center, Public Health Service, U. S. Department of Health, \\ Education, and Welfare, Fairbanks, Alaska
}

ABSTRACT: Echinococcus granulosus (Batsch, 1786) and E. multilocularis Leuckart, 1863, have been considered polytypic species, nine and three subspecies, respectively, having been recognized mainly on typological grounds. However, limits of taxonomically significant morphological and physiological variation have not been defined, nor do we know the degree to which such variation is influenced by species of host. With the probable exception of E. g. canadensis Cameron, 1960, the recognized subspecies of E. granulosus occur sympatrically with the nominate subspecies, E. g. granulosus, of European origin. Because there are no well-defined predator-prey relationships which would ensure their ecological isolation, seven of these subspecies are not reproductively segregated and therefore must be considered taxonomically invalid. Two subspecies of E. multilocularis are allopatric, but may represent two extremes of a cline; the status of the third is uncertain. Different populations (variants or physiological strains) of Echinococcus spp. might be more appropriately designated informally as strains or forms.

Attempts have been made in recent years to demonstrate the occurrence of polytypic species in the genus Echinococcus Rudolphi, 1801. Such studies have been complicated by two factors: the undefined limits of taxonomically significant morphological and physiological variation in cestodes, and the inadequate knowledge of the degree to which such variation is influenced by species of host.

Also bearing upon this difficult problem is the basic taxonomic concept of the subspecies. This has been defined by Mayr (1963, p. 348): "A subspecies is an aggregate of local populations of a species, inhabiting a geographic subdivision of the range of the species, and differing taxonomically from other populations of the species." For species of Echinococcus and other cestodes whose life cycles are similar, different host assemblages may be considered the equivalent of different subdivisions of the range. Therefore, in defining subspecies of such cestodes, evidence must be presented to show that populations occurring in assemblages of sympatric hosts are indeed segregated.

Proceeding on this basis, the present study evaluates criteria utilized in the definition of subspecies of Echinococcus spp. and reviews the taxonomic status of subspecies that have been distinguished.

\section{Species of Echinococcus}

In recent revisions of the genus, not more than four species of Echinococcus have been

Received for publication 18 January 1967. considered to be valid (Rausch and Nelson, 1963; Verster, 1965). Only two, E. granulosus and E. multilocularis, are comparatively well known. The recognized species are:

E. granulosus (Batsch, 1786) (syn. E. cameroni Ortlepp, 1934; E. felidis Ortlepp, 1937; E. intermedius López-Neyra and Soler, 1943; E. longimanubrius Cameron, 1926; E. lycaontis Ortlepp, 1934; E. minimus Cameron, 1926; E. ortleppi López-Neyra and Soler, 1943).

E. multilocularis Leuckart, 1863 (syn. E. sibiricensis Rausch and Schiller, 1954).

E. oligarthrus (Diesing, 1863) (? syn. E. cruzi Brumpt and Joyeux, 1924) (in wild felids in South America).

E. patagonicus Szidat, 1960 (in wild canids in Patagonia). E. oligarthrus and E. patagonicus are not considered further in the present paper.

\section{Recognized subspecies of $\boldsymbol{E}$. granulosus}

Europe: Verster (1965) pointed out that the type locality of the nominate subspecies of E. granulosus is in Germany. More specifically, it appears to be in the vicinity of Quedlinburg, southwest of Magdeburg, in Sachsen, where the material studied by Goeze (1782) was evidently obtained. The type host is the domestic sheep. A single form of $E$. granulosus (the nominate subspecies) presumably is present in the agricultural regions of Europe, while the form occurring within the tundra zone of Eurasia appears to be distinguishable ecologically (Rausch, 1967). The status of the latter form is discussed below. 
Cestodes from a red fox, Vulpes vulpes Linnaeus, in England, were identified by Cameron (1926) as E. granulosus. This material had been studied earlier by Ortlepp (1934, see p. 102), who made the same determination. Upon comparing the cestodes from the fox with specimens identified as E. granulosus from dogs in the vicinity of Pretoria, South Africa, Ortlepp (1934) concluded that the former were specifically distinct, and designated the species E. cameroni. After comparing some of the original specimens from the fox with $E$. granulosus from various regions, Rausch (1953) concluded that the two were morphologically indistinguishable, making $E$. cameroni a synonym of E. granulosus. Contrary to what is usually observed, E. granulosus in Great Britain is capable of maturing and producing eggs in red foxes.

E. g. equinus was described in Great Britain by Williams and Sweatman (1963), who distinguished it morphologically from $E$. granulosus occurring in New Zealand. Williams and Sweatman (p. 403) concluded that E. g. equinus is sympatric with the nominate subspecies in Great Britain. Assuming that this cestode is the same as that studied by Cameron and Ortlepp, the subspecific designation cameroni thus would have priority over equinus.

North America: E. granulosus of European origin could have been introduced into North America during the early colonial period. The earliest record in the literature, however, appeared much later; the larval cestode was observed in domestic animals in Canada by Osler (1882), who also mentioned data published in 1845 concerning infected swine in Ohio. Further reports (Salmon, 1901) and specimens in the collections of the U. S. National Museum indicate that E. granulosus was prevalent in domestic animals in the United States prior to 1900 (Rausch, 1967). At present, E. granulosus of presumed European origin is restricted to certain endemic areas, mainly in the southern part of the United States.

That the indigenous mammalian fauna was involved in the life cycle of E. granulosus in North America was first noted by Riley (1933), who found infected wolves, Canis lupus Linnaeus, and moose $(=\mathrm{elk})$, Alces alces Lin- naeus, in Minnesota. However, the form occurring in the wild mammals has been considered to be the same as that found in domestic animals farther south (Magath, 1954).

Cameron (1960) determined that the form of E. granulosus present in northern North America differs biologically from the "typical" form of European origin, and he proposed that it be designated E. granulosus var. canadensis. This cestode was later recognized as a subspecies, E. g. canadensis, by Webster and Cameron (1961). The larval stage is found in wild ruminants (wild reindeer, or caribou, Rangifer tarandus Linnaeus, and moose), as well as in man, but appears to be incapable of development in domestic animals other than domestic reindeer. Clinical differences also have been noted through the study of infections in the aboriginal peoples of Canada and Alaska (Meltzer et al., 1956; Wilson et al., unpublished data).

The subspecies E. g. borealis Sweatman and Williams, 1963, was described from material obtained from wolves and deer in Canada. Concluding that E. g. canadensis had been introduced by means of domestic reindeer and dogs imported from Norwegian Lapland, Sweatman and Williams (1963) considered E. g. borealis to be the indigenous North American form. The distinction of borealis was based upon morphological characteristics as well as upon findings in experimentally infected animals.

New Zealand: Sweatman and Williams (1963) and Williams and Sweatman (1963) determined that the nominate subspecies occurs in New Zealand and, presumably, in Australia, having been introduced into these regions with domestic animals imported from Europe (Rausch, 1967). However, Verster (1965) found that cestodes from New Zealand differed morphologically from E. g. granulosus, and the former were consequently designated E. g. newzealandensis Verster, 1965.

Africa: The cestode from South African dogs identified by Ortlepp (1934) as E. granulosus was made the type of a new species, E. ortleppi, by López-Neyra and Soler (1943). Accepting Ortlepp's original determination, Rausch and Nelson (1963) placed E. ortleppi in synonymy with $E$. granulosus. After studying some of Ortlepp's material, Verster (1965) 
concluded that these specimens were morphologically distinguishable at the subspecific level and thereupon designated them E. g. ortleppi López-Neyra and Soler, 1943.

Verster (1965) recognized the occurrence of the nominate subspecies in South Africa and assigned subspecific rank to two previously described species of Echinococcus, E. felidis and $E$. lycaontis, which had been considered synonymous with $E$. granulosus by Rausch and Nelson (1963). Besides these, E. g. africanus Verster, 1965, was distinguished, primarily on morphological grounds. Dailey and Sweatman (1965) reported both the nominate subspecies and E. g. equinus in domestic animals in Syria and Lebanon, in Asia Minor.

Nine subspecies of E. granulosus have been recognized.

\section{Recognized subspecies of $\boldsymbol{E}$. multilocularis}

Three subspecies of E. multilocularis have been distinguished. The nominate subspecies, of which the type locality is southern Germany, has a restricted geographic range in central Europe. This form presumably occurs over much of the territory of the Soviet Union.

Vogel (1957) proposed that the cestode occurring in Alaska be considered a separate geographic race or subspecies of E. multilocularis "Auf Grund gewisser Unterschiede in der Hakengrösse, Wirtsspezifität und Lokalisation der Larvenstadien . . " (p. 452). The type locality of E. m. sibiricensis is St. Lawrence Island, in the Bering Sea.

The third subspecies, E. m. kazakhensis Shul'ts, 1961, distinguished by the ability of the larval stage to develop in ungulates, evidently has been recorded only from Kazakhstan.

\section{The taxonomic validity of infraspecific categories in cestodes of the genus Echinococcus}

The comparatively great age of the species of mammals comprising the fauna of what is now Europe has been established from paleontological evidence (Charlesworth, 1957; Zeuner, 1958). Since adaptation of a cestode to its hosts involves a long evolutionary process (Baer, 1934, 1946; Stunkard, 1957), the species of cestodes occurring in these mammals must have existed as such since some time before the end of the last interglacial period
(Riss/Würm). Many of the species of mammals serving as hosts of E. granulosus and $E$. multilocularis at higher latitudes are holarctic in distribution (Rausch, 1963).

The life cycle of $E$. granulosus involved the wolf and wild ungulates of various species. By early postglacial time, the wolf was present extensively in Eurasia, but the ungulates serving as the intermediate host of E. granulosus were segregated to some degree both ecologically and geographically. The essential intermediate hosts within the tundra zone were the wild reindeer and probably the elk (moose). Farther south, in the European forested zone, the intermediate host of this cestode included several species (wild swine, Sus scrofa Linnaeus; aurochs, Bos primigenius Bojanus; red deer, Cervus elaphus Linnaeus, and others). The $\operatorname{dog}(=$ wolf $)$ was domesticated in Europe during late mesolithic time (Charlesworth, 1957; Clutton-Brock, 1963). With the domestication of ungulates of various species, conditions favoring the existence of a synanthropic cycle of $E$. granulosus came into being. The natural cycle involving the wolf and wild ungulates coexisted in Europe with the synanthropic cycle. With the extirpation of the wolf in Europe, the natural cycle of E. granulosus was largely destroyed, although the dog replaced the wolf to some extent as a source of infection for the remaining wild ungulates (deer and wild swine). The wolf-reindeer cycle has persisted at higher latitudes, although there also the dog and the domestic reindeer have partially replaced the natural hosts.

The nominate subspecies of E. granulosus, adapted in the larval stage to development in domestic animals, became widely distributed following the introduction of such animals into different regions of the world during the period of conquest and colonization in the 18th and 19th centuries (Rausch, 1967). This cestode had no doubt become established much earlier in Africa and southern Asia, but a succession of reintroductions must have taken place during the period of colonization. The northern form of E. granulosus could not have been distributed to any significant extent to other parts of the world, although cestodes possessing some of the characteristics of both forms might have been introduced occasionally with domestic animals originating in marginal 
agricultural areas of northern Europe. After about 1890, infected reindeer and/or dogs could have been brought into Alaska and northern Canada, where presumably the northern form of E. granulosus was already present.

For E. multilocularis, foxes (Vulpes and Alopex) serve as the final host, and small mammals, particularly microtine rodents, contain the larvae. Under conditions modified by man, the dog also is an important final host. Although the pattern of geographic distribution of E. multilocularis is in some ways curiously restricted (Rausch, 1967), the original geographic range of this cestode seems not to have been extensively modified.

\section{Subspecies of E. granulosus}

Two biologically different forms of E. granulosus thus are seen to exist in western Eurasia, but from all evidence the two cannot be distinguished morphologically. The recognized subspecies of $E$. granulosus have been discussed below in reference to this hypothesis.

Modern taxonomic concepts preclude the sympatric existence of more than one subspecies of a single polytypic species. Assuming that different host assemblages are equivalent to different subdivisions of the geographic range of a free-living animal, conceivably two or more subspecies of $E$. granulosus could exist in sympatric hosts if segregated in different host assemblages by comparatively rigid predator-prey relationships. That such is the case in any area where two or more subspecies of this cestode have been recognized is not apparent.

In Great Britain, two sympatric subspecies of E. granulosus (E. g. granulosus and E. g. equinus) occur in the same hosts. The important final host is undoubtedly the dog, and the larval stage is found at least in horses and sheep if not in other ungulates (Williams and Sweatman, 1963; Cook and Crewe, 1963). E. granulosus in Great Britain can develop and produce eggs in red foxes, which probably serve as a source of infection for domestic animals. However, we cannot consider as realistic the proposal that a natural predatorprey relationship exists between foxes and the comparatively much larger ungulates. Both dogs and foxes must almost always become infected through feeding upon carrion or offal. The occurrence of gravid specimens of $E$. granulosus in foxes of the genus Vulpes is not so unusual as was believed, in view of findings in other regions (Shumakovich and Nikitin, 1959; Gorina, 1959; Malczewski, 1963). That E. g. granulosus and E. g. equinus are in any way segregated cannot be supported; therefore, the latter taxon must be considered invalid.

The situation is somewhat more complex in North America, where the geographic range of the indigenous form of $E$. granulosus encompasses at least the zones of tundra and boreal forest, while the southern limits are unknown (Rausch, 1967). E. g. granulosus of European origin was introduced into the agricultural regions of the United States and southern Canada, and after attaining maximum geographic distribution in domestic animals around 1900 , has been largely eliminated through the control of abattoirs. These two forms of $E$. granulosus have remained essentially allopatric in their North American distribution, although some overlapping of their ranges probably occurred in marginal agricultural areas at about the latitude of the border between the United States and Canada. However, if such overlapping did occur, no evidence of intergradation between these forms has been detected. The status of E. g. granulosus in North America seems to be well defined.

In northern North America, however, two sympatric subspecies of E. granulosus have been recognized. Sweatman and Williams (1963) concluded that E. g. canadensis was introduced with reindeer and dogs from Norwegian Lapland, while $E$. g. borealis represents the indigenous North American subspecies. Again, two subspecies allegedly occur in sympatric hosts not segregated ecologically. If, as Sweatman and Williams believe, the form designated E. g. canadensis was introduced from Lapland, it would presumably be identical with the indigenous North American form, there being probably a single, holarctic form at higher latitudes. In any event, an introduced subspecies of E. granulosus could not retain its genetic identity in the absence of a segregating mechanism. Any genetic differences that might have existed would disappear in the resulting common gene pool, since by definition the different subspecies of a polytypic species interbreed if not segregated. 
Thus, E. g. canadensis could not exist as an infraspecific entity; further, that a distinctive organism was in fact introduced is doubtful. Under these circumstances, only a single subspecies could be recognized. If the indigenous North American cestode were to be designated as a distinct subspecies, $E$. g. borealis on the basis of priority would have to be suppressed in favor of E. g. canadensis.

In another region, South Africa, the mammalian fauna would seem to be sufficiently varied to permit the existence of different host assemblages segregated by well-defined predator-prey relationships. The existence of polytypy within $E$. granulosus might thus be expected, but this in actuality does not appear to be the case. Verster (1965) recognized five subspecies of E. granulosus in the Transvaal region of South Africa, primarily on morphological grounds: E. g. africanus, E. g. felidis, E. g. granulosus, E. g. lycaontis, and E. g. ortleppi. With the possible exception of $E$. g. felidis in the lion (Panthera leo Linnaeus), about which little is known, a significant degree of ecological isolation or host specificity in the strobilar stages of these cestodes is not evident. Neither do the respective larval stages exhibit an appreciable degree of host specificity. Strobilae identified as those of $E$. $g$. africanus and E. g. ortleppi were obtained in experimentally infected canine animals from larvae from cattle, and cestodes identified as E. g. africanus and E. g. lycaontis were similarly reared from larvae from domestic sheep. Larvae of E. g. granulosus were obtained by Verster also from man and domestic swine. Larval Echinococcus were not recorded in the Transvaal from wild ungulates that comprise the major prey of the lion or of the hunting dog, Lycaon pictus Temminck. As in Kenya (Nelson and Rausch, 1963), E. granulosus appears to be propagated essentially by domestic animals, including the dog, in South Africa.

The view that more than a single subspecies of E. granulosus occurs in South Africa is supportable only by evidence of ecological segregation or marked host specificity. Lacking such evidence, as is the case, we must regard four subspecies (africanus, felidis, lycaontis, and ortleppi) to be synonyms of E. g. granulosus.

The remaining subspecies, E. g. newzealandensis, Verster (1965) found to differ morphologically from E. g. granulosus from Germany. A well-documented history exists of introductions of domestic animals of European origin into New Zealand. This and our knowledge of the absence in New Zealand of an indigenous form of Echinococcus uphold the conclusion that the differences attributed to $E$. g. newzealandensis probably represent nonsignificant variation in cestodes belonging to the nominate subspecies.

Morphological data of impressive quantity are available on subspecies of E. granulosus. A review of these makes apparent that the systematic concepts upon which published work was based were largely typological, perhaps because the amount of material studied was insufficient to provide an understanding of the limits of morphological variation within local populations of E. granulosus. Relevant to this is the view of Mayr et al. (1953), who pointed out that populations of an animal may be statistically different, but not as a consequence necessarily taxonomically different.

Sweatman and Williams (1963) and Williams and Sweatman (1963) relied upon characteristics of rostellar hooks of both larval and strobilar stages as well as upon number of segments, relative position of the mature segment, number and distribution of testes, and structure of the cirrus sac and seminal vesicle. Verster (1965), on the other hand, found that the size of the rostellar hooks in the adult cestode varied with species of final host; moreover, she was unable to confirm that the ultimate size of rostellar hooks is fixed in the larval stage, as Sweatman and Williams (1963) believed. Verster depended largely upon number of segments, relative position of the mature segment, and distribution and number of testes, in order to distinguish subspecies of $E$. granulosus.

The apparent, though slight, differences that she observed in material obtained in experimentally infected animals evidently represented host-species induced variation, combined in some cases with physiological modifications. The series of animals utilized were in general too small to exclude as an influence the possible effects of dissimilarities in degree of susceptibility among animals of the same species. Although Verster expressed some reservations concerning the reliability of the 
criteria she employed, she considered recognition of subspecies of $E$. granulosus to be appropriate until these bases were shown to be invalid. However, since the described subspecies of this cestode must be rejected on other grounds, the evaluation of morphological criteria at the infraspecific level is not essential here.

\section{Subspecies of E. multilocularis}

All of the recognized subspecies of E. multilocularis are allopatric. E. m. multilocularis and E. m. sibiricensis differ relatively in site of localization of the larva in the intermediate host and in host specificity of the strobilar stage (Vogel, 1957). The form of E. multilocularis in central North America may exhibit variations of similar magnitude (Rausch and Richards, unpublished data), and other variants may be recognized in the future, particularly in the Soviet Union.

E. m. kazakhensis was originally reported from sheep in Kazakhstan, where up to $8 \%$ of Echinococcus-infected animals contained larvae of alveolar type (see Abuladze, 1964, p. 358). The adult cestode occurs in dogs. More recently, the larval stage of Alveococcus (= Echinococcus) multilocularis, as well as that of $E$. granulosus, have been reported from wild swine, Sus scrofa, in the same region (Shol', 1963).

\section{DISCUSSION}

Our inadequate understanding of the limits of intraspecific variation in cestodes of the genus Echinococcus has been a source of uncertainty at both the specific and infraspecific levels. Smyth and Smyth (1964), for example, concluded that E. granulosus and E. multilocularis represent the two extremes of a charactergradient comprising an indefinite number of variants which may exhibit characteristics common to both. Their interpretation appears to be largely the result of placing emphasis on host-induced variation in larval cestodes developing in other than their natural hosts. The limits of normal intraspecific variation in these cestodes must be determined through the study of material from the natural hosts, i.e., those mammals which perpetuate the cestodes under conditions unmodified by man. Under natural conditions also the larval stages of these ces- todes may develop in fortuitously infected mammals of species that obviously cannot be included in the respective host assemblages (e.g., the larval E. multilocularis in Sorex); however, the status of such accidental hosts can be readily determined by means of ecological investigations.

Intraspecific variation in Echinococcus might be made more understandable if certain uniform conditions were assured in experimental studies. Yamashita et al. (1958), for example, demonstrated that uniform strains of white mice varied widely in the degree to which they supported development of the larval E. multilocularis. Of similar magnitude might be the variation resulting in different genetic strains of domestic animals or even in wild animals of the same species originating from widely separated localities. Consequently, results of investigations in different parts of the world with animals of the same species are not necessarily comparable. Not only should experimental animals be uniform genetically, but differences in age and nutritional status may be reflected in the results. In infecting dogs of a pure strain (beagle) with E. multilocularis, I have found that the results are not always uniform in members of single litters which received the same quantity of infective material from a single source. When experimental studies involve small series of animals, either as final or intermediate hosts, apparent differences in results should be evaluated with caution.

As the recent investigations have shown, local populations of $E$. granulosus are intrinsically variable morphologically. Genetic variability of the cestodes in combination with effects related to species of host seems to account for the statistically demonstrable but taxonomically insignificant differences that have been described. The dissimilarities existing between the two comparatively well known forms or populations of E. multilocularis may be taxonomically significant. In view of the extensive geographic range of the species, the central European and Alaskan forms may represent two extremes of a cline. Until new information becomes available to indicate otherwise, it seems appropriate to designate different populations of E. granulosus and E. multilocularis informally, as strains or forms. 


\section{ACKNOWLEDGMENTS}

To Professor Ernst Mayr, Museum of Comparative Zoology, Harvard University, and Dr. Francis H. Fay, Arctic Health Research Center, who read the manuscript of this paper, I express my thanks.

\section{LITERATURE CITED}

Abuladze, K. I. 1964. Teniaty-lentochnye gel'minty zhivotnykh i cheloveka i vyzyvaemye imi zabolevaniia. Osnovy tsestodologii 4, Akad. Nauk SSSR, Moscow, 530 p.

BAER, J. G. 1934. L'adaptation des helminthes à leurs hôtes. Bull. Soc. Neuchât. Sci. Nat. 58: $57-76$.

1946. Les helminthes parasites des vertébrés. Relations phylogéniques entre leur évolution et celle de leurs hôtes. Conséquences biologiques et médicales. Premier Colloque Franco-Suisse. Parasitologie. Besançon. p. 1-26.

Cameron, T. W. M. 1926. Observations on the genus Echinococcus Rudolphi, 1801. J. Helm. 4: 13-22.

- 1960. The incidence and diagnosis of hydatid cyst in Canada. Echinococcus granulosus var. canadensis. Parassitologia 2: 381390.

Charlesworth, J. K. 1957. The Quaternary Era with special reference to its glaciation. Vol. 2. Edward Arnold, London, p. 5951700 .

Clutton-Brock, J. 1963. The origins of the dog. p. 269-274. In D. Brothwell and E. Higgs (eds.), Science in archaeology. A comprehensive survey of progress and research. Basic Books, Inc., New York, 595 p.

Cook, B. R., ANd W. Crewe. 1963. The epidemiology of Echinococcus infection in Great Britain. I.-Abnormal behaviour of sheep in the mining valleys of South Wales and its relation to hydatid disease in man. Ann. Trop. Med. Parasit. 57 : 150-156.

Dailey, M. D., and G. K. Sweatman. 1965. The taxonomy of Echinococcus granulosus in the donkey and dromedary in Lebanon and Syria. Ann. Trop. Med. Parasit. 59: 463477.

Goeze, J. A. E. 1782. Versuch einer Naturgeschichte der Eingeweidewürmer thierischer Körper. Blankenburg, $471 \mathrm{p}$.

Gorina, N. 1959. K voprosu o roli lisits v epizootologii i epidemiologii odnokamernogo ekhinokokkoza. Helminthologia 1: 221-223.

López-Neyra, C. R., AND M. DE LOS A. SOlER. 1943. Revisión del género Echinococcus Rud. y descripción de una especie nueva parárita [sic] intestinal del perro en Almería. Rev. Ibér. Parasit. 3: 169-201.

Magath, T. B. 1954. The importance of sylvatic hydatid disease. J. Am. Vet. Med. As. 125: 411-414.
Malczewski, A. 1963. The red fox Vulpes vulpes $\mathrm{L}$. as the final host of the tapeworm Echinococcus granulosus (Batsch, 1786) in Poland. Bull. Acad. Pol. Sci. 11: 295-296.

MAYR, E. 1963. Animal species and evolution. Belknap Press, Harvard Univ. Press, Cambridge, $797 \mathrm{p}$.

$\longrightarrow$, E. G. LinSLEy, AND R. L. Usinger. 1953. Methods and principles of systematic zoology. McGraw-Hill Book Co., New York, 336 p.

Meltzer, H., L. Kovacs, T. ORford, and M. Matas. 1956. Echinococcosis in North American Indians and Eskimos. Can. Med. As. J. 75: $121-128$.

Nelson, G. S., and R. L. Rausch. 1963. Echinococcus infections in man and animals in Kenya. Ann. Trop. Med. Parasit. 57: 136149.

Ortlepp, R. J. 1934. Echinococcus in dogs from Pretoria and vicinity. Onderstepoort J. Vet. Sci. and Animal Ind. 3: 97-108.

OsLer, W. 1882. On echinococcus disease in America. Am. J. Med. Sci. 84: 475-480.

Rausch, R. L. 1953. The taxonomic value and variability of certain structures in the cestode genus Echinococcus (Rud., 1801) and a review of recognized species. Thapar Commemoration Vol. Lucknow, p. 233-246.

1963. A review of the distribution of holarctic recent mammals. Pac. Basin Biogeogr., 10th Pac. Sci. Cong. 1961. Bishop Mus. Press, Honolulu, p. 29-43.

1967. On the ecology and distribution of Echinococcus spp. (Cestoda: Taeniidae), and characteristics of their development in the intermediate host. Ann. Parasit. In press.

—, AND G. S. Nelson. 1963. A review of the genus Echinococcus Rudolphi, 1801. Ann. Trop. Med. Parasit. 57: 127-135.

RILEY, W. A. 1933. Reservoirs of Echinococcus in Minnesota. Minn. Med. 16: 744-745.

SAlmon, D. E. 1901. Pathological conditions found in meat inspection. J. Am. Med. As. 36: $867-871$.

Shol', V. A. 1963. Fauna gel'mintov kabanov (Sus scrofa L.) Kazakhstana. Trudy Inst. Zool., Akad. Nauk Kazakh. SSR, Alma-Ata. 19: 97-100.

Shumakovich, E. E., AND V. F. Nikitin. 1959. $\mathrm{K}$ obnaruzheniiu Echinococcus granulosus (Batsch, 1786) u korsaka. Biull. Nauch.tekhn. Inf. Vsesiouz. Inst. Gel'mint. im. K. I. Skriabina, No. 5, p. 98-99.

Sмyth, J. D., ANd M. M. Sмyтh. 1964. Natural and experimental hosts of Echinococcus granulosus and E. multilocularis, with comments on the genetics of speciation in the genus Echinococcus. Parasitology 54: 493-514.

Stunkard, H. W. 1957. Host-specificity and parallel evolution of parasitic flatworms. Ztschr. Tropenmed. Parasit. 8: 254-263.

Sweatman, G. K., and R. J. Williams. 1963. Comparative studies on the biology and mor- 
phology of Echinococcus granulosus from domestic livestock, moose and reindeer. Parasitology 53: 339-390.

Verster, A. J. M. 1965. Review of Echinococcus species in South Africa. Onderstepoort J. Vet. Res. 32: 7-118.

VOGEL, H. 1957. Über den Echinococcus multilocularis Süddeutschlands. I. Das Bandwurmstadium von Stämmen menschlicher und tierischer Herkunft. Ztschr. Tropenmed. Parasit. 8: $404-454$.

Webster, G. A., and T. W. M. Cameron. 1961. Observations on experimental infections with Echinococcus in rodents. Can. J. Zool. 39: 877-892.
Williams, R. J., and G. K. Sweatman. 1963. On the transmission, biology and morphology of Echinococcus granulosus equinus, a new subspecies of hydatid tapeworm in horses in Great Britain. Parasitology 53: 391-407.

Yamashita, J., M. Ohbayashi, Y. Kitamura, K. SuzuKI, and M. OKugi. 1958. Studies on echinococcosis VIII. Experimental Echinococcosis multilocularis in various rodents; especially on the difference of susceptibility among uniform strains of the mouse. Jap. J. Vet. Res. 6: 135-155.

ZeUner, F. E. 1958. Dating the past. An introduction to geochronology. Methuen and Co., Ltd., London, 516 p. 